\title{
ジルコニア系セラミックスの マルテンサイト変態と強勒化
}

早川元 造* 岡 宗 雄*

\section{1. は じめに}

ジルコニアのマルテンサイト変態がセラミックスの強勒化 に利用できることが Garvie ら(1)によって初めて示されてか ら20年が経過する。午の間, 開発当初の析出型の「部分安 定化ジルコニア」に加えて, 単相型の「正方晶ジルコニア多 結晶体」やアルミナ等にジルュニア粒子を分散させた「ジル コニア勒化セラミックス」等の新しい形態の材料が開発され てきたし, 個々の材料について子出発原料や製法の吟味・改 良により高品質化されてきている。しかしながら，この一連 の材料は使用温度が常温近辺に限られることや $400 \sim 600 \mathrm{~K}$ の保持で劣化すること等の欠点もあり, 全体としてのコス ト/パーフォーマンスの点から利用は限られたものになって いる.

一方, これらの材料の強勒性はジルコニアのマルテンサイ 卜変態に起因しているので, ジルコニアのマルテンサイト変 態挙動に関する研究も精力的に行われてきている. 変態挙動 自身が学術的に興味深い研究対象であるが，无の成果はこの 材料のさらなる改良や, 理論的に可能な強勒化の上限を見通 すのに有用である。マルテンサイト变態の研究分野は多岐に わたるが，ここではマルテンサイト変態による勒化機構につ いて述べた後, マルテンサイト変態の中心的課題である変態 の結晶学と変態挙動の結晶粒径依存に関して著者らの研究結 果を中心に紹介する.

\section{2. マルテンサイト変態による靭化機構}

Griffith によると完全弾性体の破壊強度は次式で与えられ る.

$$
\sigma_{\mathrm{f}}=\sqrt{\frac{2 \gamma E}{\pi c}}
$$

ここで $E$ はヤング率， $\gamma$ は比表面エネルギー，cはき裂長さ である、教はき裂長さ $c$ 以依存するが，もしき裂が全く存 在しなければ, 破壊強度は式(1)ではなく式(2)の理想破 壊強度式が適用される。

$$
\sigma_{\mathrm{th}}=\sqrt{\frac{\gamma E}{r_{0}}}
$$

ここで $r_{0}$ は䢃開面の原子面間距離である。式 (1)と式 (2) が等しくなるcは $0.64 r_{0}$ で, この程度のき裂や欠陥はどの ような材料にも存在するので, 結局完全弾性体については式 (1)のみを考光ればよいことになる。

式 (1)を見て, $\gamma$ 扝よび $E$ は構造鈍感な材料定数である ので，破壊強度を上げるにはさ裂長さを小さくする以外に方 法が無いよらよらに見光るが必ずしもそらではない， $\gamma$ は単 位面積当たりのき裂に対する表面エネルギーであるので, 破 面を複雑にしたり，裂の進展に伴って余分なエネルギーを 消費させることにより見かけの表面エネルギーを增师させる ことができる。この過制表面エネルギーを $\gamma_{\mathrm{p}}$ と置くと式 (1) は式(3)のように表壮る.

$$
\sigma_{\mathrm{f}}=\sqrt{\frac{2 E\left(\gamma+\gamma_{\mathrm{p}}\right)}{\pi c}}
$$

一方, き裂先端の応力場は平均負荷応力 $\sigma$ 之き裂長さ $c$ に

\footnotetext{
* 鳥取大学教授; 工学部機械工学科 (

Martensitic Transformation and Toughening of Zirconia Ceramics; Motozo Hayakawa, Muneo Oka (Department of Mechanical Engineering, Faculty of Engineering, Tottori University, Tottori)

Keywords: zirconia, partially stabilized zirconia, tetragonal zirconia polycrystal, martensitic transformation, transformation toughening, crystallographic mechanism, grain size dependence

1994年 9 月 1 日受理
} 
よって次式で与えられる.

$$
K_{\mathrm{I}}=\sigma \sqrt{\pi c}
$$

これを応力拡大係数と呼ぶが, これがある臨界值に達したと きにき裂が進展する．この臨界值を破壊勒性值と呼び $K_{\mathrm{Ic}}$ で 表すが，式( 3 )を考慮すると次式が得られる.

$$
K_{\mathrm{Ic}}=\sigma_{\mathrm{f}} \sqrt{\pi c}=\sqrt{2 E\left(\gamma+\gamma_{\mathrm{p}}\right)}
$$

あるいは，

$$
\sigma_{\mathrm{f}}=K_{\mathrm{Ic}} / \sqrt{\pi c}
$$

すなわち，脆性材料の破壊勒性值は $\gamma_{\mathrm{p}}$ を付加することによ り上昇し，それに伴い破壊強度も上昇する. ジルコニアの変 態勒化はこの材料のマルテンサイト変態を利用して $\gamma_{\mathrm{p}}$ を上 昇させることであるが, 式(6)の破壊強度と破壞勒性值の 比例関係には限度があり，それを越えて勒化を図ろらとする と破壊強度は逆に低下寸る。これについては後で述べる。

ジルコニアの変態勒化機構について述べる前に, 変態勒化 セラミックスの 3 つ代表的な形態について述べて拉く. まず最初に Garvie ら (1)によって開発されたものは, 安定 c 相中に準安定な $\mathrm{t}$ 相粒子を析出反応により分散させたもので あり, 通常, 部分安定化ジルコニア (PSZ) といえばこの型を 指す. 安定化剂としてはカルシアとマグネシアが一般的であ る. 次に Gupta ら ${ }^{(2)}$ にって開発されたものは微細な準安 定 $\mathrm{t}$ 相粒のみから構成されるもので正方晶ジルュニア多結晶 体(TZP) と呼ばれている. 安定化剂としてはイットリアが 一般的であるが，七リアや他の希土類酸化物を用いても同様 のものが得られる. 三番目はアルミナ等のセラミックス中に ジルコニアの微細な $\mathrm{t}$ 相を準安定状態で分散させたものであ ク, ジルコニア勒化セラミックス(ZTC)の一般名で呼ばれ ている(3).このように変態勒化セラミックスはすべて準安定 な $\mathrm{t}$ 相を含をが，この相の存在がぞのように勒化に寄与する かを次に示す。

ジルコニアは常圧に扎いて高温側より立方晶相 (c 相), 正 方晶相 $(\mathrm{t}$ 相) 括よび, 単斜晶相 ( $\mathrm{m}$ 相)の 3 相が存在する. こ のらち $\mathrm{t} \rightarrow \mathrm{m}$ 変態はマルテンサイト的に起こる. この変態は $1200 \mathrm{~K}$ 付近で起こり, 数\%の体積膨張を伴らので高温から の冷却中にき裂を生じ，材料は破壞してしまう．このため, 純ジルコニアの緻密な焼結体は高温構造用材料として使用す ることができない。

ジルコニアにカルシア，マグネシア，イットリア，セリア 等の酸化物を固溶させると, $\mathrm{c}$ 相や $\mathrm{t}$ 相の存在領域が低温側 にシフトする.すなわち高温相が安定化される. 図 1 亿例之 してジルコニアーイットリア系の状態図(4)を示すが，他の酸 化物でも類似の状態図となる. ジルコニア系では $1600 \mathrm{~K}$ 以 下での拡散速度は極めて遅いので, 図 1 の $1600 \mathrm{~K}$ 以下の領 域は高温側のデータの外挿抢よび想像によって描かれてい る. 実際には $\mathrm{t}$ 相から $\mathrm{m}$ 相の析出反応 $\mathrm{t} \rightarrow \mathrm{m}+\mathrm{c}$ の共析反 応は起こらず, 斜線で示した温度範囲で $\mathrm{m}$ 相にマルテンサ イト変態するか, 準安定状態で室温までもち来されるかのい ずれかとなる.ちなみに $\mathrm{c}$ 相領域から冷却したとき室温で

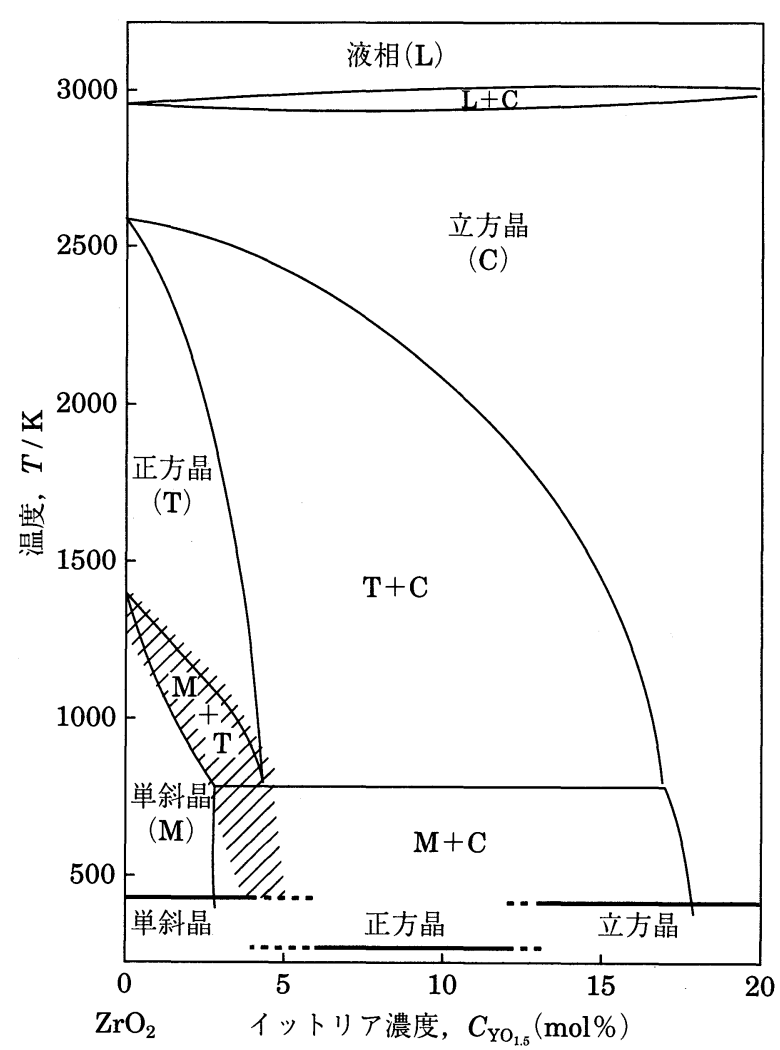

図 1 ジルコニアーイットリア系状態図 ${ }^{(4)}$.

存在する相の種類が状態図の下部に示してある.

準安定な $\mathrm{t}$ 相は $\mathrm{t}-\mathrm{m}$ 相間の平衡温度 $T_{0}$ からの過冷や応力 負荷に上って自由エネルギー差 $\left(\Delta G=G_{\mathrm{m}}-G_{\mathrm{t}}\right)$ が，ある臨界 値に達したときにマルテンサイト変態する，実用化されてい る部分安定化ジルュニアはこの $\Delta G$ が極めて大きく, 液体 窒素温度に冷却しても変態しないのが普通であるが，き裂先 端の高応力場では局所的な变態が起こる.このような応力誘 起変態はエネルギー消費過程であり, 式 (3)あるいは式 (5) の $\gamma_{\mathrm{p}}$ の上昇をもたらすので, 破壊強度あるいは破壊勒性の 向上をもたらす.この過程による単位面積当たりのき裂に対 寸るエネルギー消費の目安は次式で与兄られる(5).

$$
\Delta G_{\mathrm{c}}=2 V e^{\mathrm{T}} \sigma_{\mathrm{m}}^{\mathrm{c}} h
$$

ここで, $V$ は変態領域中に含まれる变態相の体積分率, $e^{\mathrm{T}}$ は変態歪 (アイゲン歪)で双晶や自己調整機構によって剪断歪 は緩和されていると仮定している， $\sigma_{\mathrm{m}}^{\mathrm{c}}$ は臨界変態誘起応力, $h$ は変態領域の厚さである. $h$ は次式で $\sigma_{\mathrm{m}}^{\mathrm{c}}$ に関保づけられ ている(5).

$$
h=\frac{\sqrt{3}(1+v)^{2}}{12 \pi}\left[\frac{K_{\mathrm{I}}}{\sigma_{\mathrm{m}}^{\mathrm{c}}}\right]^{2}
$$

式(7)拉よび $(8)$ より， $\sigma_{\mathrm{m}}^{\mathrm{c}}$ が低いほど $h$ が大きくなり，か つ $\Delta G_{\mathrm{c}}$ が高くなることが分かる. 応力拡大係数を用いた考 え方によっても同様の式が導かれるが, 詳細は文献(5) 飞譲 る.

上記のことより， $\sigma_{\mathrm{m}}^{\mathrm{c}}$ が低い汪ど，すなわち， $\mathrm{t}$ 相の安定 
度が低く，比較的低い応力で容易に変態が誘起されるほど勒 化には効果的である。しかしながら $\sigma_{\mathrm{m}}^{\mathrm{c}}$ があまり低くなる と，マルテンサイトがき裂先端ばかりではなく，より広範な 領域で変態バンドが形成される。このような変態バンド中に は変態歪のミスマッチによる微小き裂が生成し，これらが新 たな破壊源となるため破壊強度は逆に低下する。このよらな 状況をEvans と Cannon ${ }^{(6)}$ は図 2 のよらにまとめている. $\sigma_{\mathrm{m}}^{\mathrm{c}}$ が高い領域ではき裂先端での応力誘起変態が勒化に寄与 するので， $\sigma_{\mathrm{m}}^{\mathrm{c}}$ の低下とともに破壊強度は双曲線的に上昇す る. $\sigma_{\mathrm{m}}^{\mathrm{c}}$ が低い領域では変態降伏が広範に起こるため $\sigma_{\mathrm{m}}^{\mathrm{c}} に$ 比例して破壊強度が低下寸る．最大の破壊強度はある特定の $\sigma_{\mathrm{m}}^{\mathrm{c}}$ によって与えられるが，この最適値は既存の欠陥サイズ に依存する。最近 Ce-TZP が Y-TZP を上回る破壊勒性を示 すことより注目されているが，破壊強度はY-TZPより劣 る.これは $\sigma_{\mathrm{m}}^{\mathrm{c}}$ が低すぎて変態降伏を起こすためである.こ のような理由で強度・勒性ともに上昇させるためには $\mathrm{t}$ 相の 安定性を最適なものに調整する必要がある.

\section{3. マルテンサイト変態の結晶学}

マルテンサイト変態は無拡散的な一次相変態の 1 つであ り, 剪断丕を主成分とする格子変形によって起こる ${ }^{(7)}$. 変態 が起こるか否かは自由エネルギー変化によって議論できる が，マルテンサイト変態に伴う自由エネルギー変化は次式で 表せる。

$$
\Delta G=\Delta G_{\mathrm{ch}}+\Delta G_{\mathrm{st}}+\Delta G_{\mathrm{s}}+\Delta G_{\mathrm{d}}
$$

ここで $\Delta G_{\mathrm{ch}}$ はマルテンサイト相と母相の化学的自由エネル ギーの差 $\left(G_{\mathrm{ch}}^{\mathrm{m}}-G_{\mathrm{ch}}^{\mathrm{t}}\right)$ であり, $\Delta G_{\mathrm{st}}$ は形状変形によって生じ る歪エネルギー, $\Delta G_{\mathrm{s}}$ は母相-マルテンサイト相界面や双晶 界面等の界面エネルギー, $\Delta G_{\mathrm{d}}$ は変態時に発する衝撃波や 熱等の不可逆的に散逸するエネルギーである. 変態が自発的 に起こるには $\Delta G$ が負でなければならないが，右辺の第 2

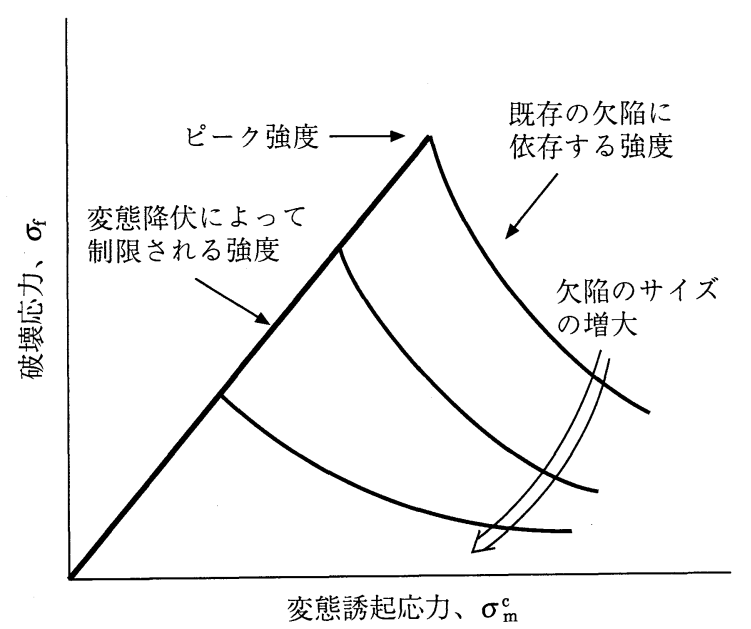

図 2 破壊強度と変態誘起応力との関係の模式図.
項以降はすべて正であるので， $\Delta G_{\mathrm{ch}}$ は必然的に負でなけれ ばならない。すなわち母相一マルテンサイト相間の熱力学的 平衡温度 $\left(T_{0}\right)$ よりある程度以上の過冷が必要であるが，そ の大きさは右辺第 2 項以降の大きさに依存する. また $\Delta G_{\mathrm{d}}$ は正·逆変態何れの場合も正に働くので変態温度 · 逆変態温 度には差が生じる.すなわらヒステリシスが存在する.

$\Delta G_{\text {st }}$ はマルテンサイト板の形状と形状歪によって決まる が, 弾性論的解析より, 板状の領域がその広い面の歪を 0 に保つ歪(不変面歪といら)で変形した場合, 全歪エネルギー を最小にすることができる．実際理想的に生成したマルテン サイト板の形状歪を測定すると不変面歪条件を満たしてい る. 一方, 母相からマルテンサイト相への変態に伴ら格子歪 は一般に不変面歪とはなり得ない，この一見矛盾する現象は 補足歪の導入によって解消でさる. すなわち, ある領域が格 子歪により母相からマルテンサイト相に変態した後, マルテ ソサイト板中に細かいスケールで適当量のすべりや双晶によ る変形が起こるとマルテンサイト全体としての歪は不変面歪 となり得る．このようなすべりや双晶変形はマルテンサイト 相の格子を変えないので格子不変歪と呼ばれる. 実際このよ うな補足歪が起こっていることは電顕観察より明らかにされ ている.

上記の変態機構を 3 行 3 列の行列を用いた数式で表すと 次式のようになる(8).

$$
\boldsymbol{S}=\boldsymbol{R P B}
$$

ここで $B$ は格子雨, $P$ は格子不変歪, $R$ は剛体回転, $S$ は マルテンサイト板の形状歪であり不変面歪であることを前提 としている(格子不変歪を母相中にとって, 式(10)の代わり に $\boldsymbol{S}=\boldsymbol{R} \boldsymbol{B P}$ とすることもある.). $\boldsymbol{B}$ は母相とマルテンサイ 卜相間の格子対応と格子定数より精度良く計算できる．P に関しては電顕観察よりすべりであるか双晶であるかが判定 でき, さらに剪断面や剪断方向も推定できる. 電顕観察が可 能でない場合でもマルテンサイト相の結晶構造より可能なす ベり系や双晶系をある程度予測できる.すなわち $\boldsymbol{P}$ の剪断 量は分からなくともその剪断系(面と方向) は推定できる. 式 (10)で注目すべき点は $\boldsymbol{B}$ 扣よび $\boldsymbol{P}$ の剪断系が分かれば， $\boldsymbol{S}$ が不変面歪であるといら条件のもとに式(10)を完全に解く ことができることである。

式(10)が解けると, マルテンサイト板の晶癖面, 形状䄳, 格子の方位関係等が計算できる。これらは測定によっても求 められるので, 計算結果と測定結果が一致すれば式(10)の $\boldsymbol{B}$ や $\boldsymbol{P}$ を得るための前提が正しかったと結論できる. 一般 に式(10)が解けたことをもってマルテンサイト変態の結晶 学が明らかになったとする.このよらな手法をマルテンサイ 卜変態の現象論と呼んでいるが, 金属材料のマルテンサイト 変態の解析に多大の貢献をしてきた. ジルュニアのマルテン サイト変態に対しても同様の解析法が適用できるが，解析例 は限られている.

ジルコニアのマルテンサイト変態に初めて現象論的解析を 
行ったのはBansal とHeuer(9)(10)である.ジルコニアの場合, $\mathrm{t}$ 相と $\mathrm{m}$ 相の間には, $\mathrm{t}$ 相の $\mathrm{c}$ 軸が $\mathrm{m}$ 相のいずれの軸に対 応するかによって, わずかに異なる 3 種類の格子対応が存 在する。屯た，格子不変歪に関しては全く未知の状態であっ たので, Bansal とHeuer は母相の低指数面・低指数方向の すべり系を仮定し，上述の3つの格子対応とのすべての組 合せについて計算を行った。彼らは32個の解の内，(110) $[001]_{\mathrm{t}}$ および $(1 \overline{1} 0)[110]_{\mathrm{t}}$ すべりを格子不変歪とした解が， 実測された $(671)_{\mathrm{m}}$ 㸝よび $(761) \mathrm{m}$ 晶癖面を説明することを示 した。しかしながら，彼らの実験では純ジルコニアの $\mathrm{m}$ 相 単結晶を初期試料として用いて抢り, $\mathrm{t}$ 相まで加熱後室温ま で冷却した状態では完全に $\mathrm{m}$ 相に変態しだ状態であったの で，実測された晶癖面が真に母相に対して無歪面であったか

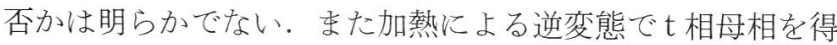
ているが，この逆変態が次に起こるマルテンサイト変態に何
らかの影響を及湆している可能性もある。市た測定值との比 較が晶癖面のみについて行われ, 形状歪や格子不变歪系等に 関しては実施されていない。これらのことより結果の正当性 については定かでない，その後 Kriven ら (11)や Choudhry と Crocker ${ }^{(12)}$ にってさらに多くの格子不変歪を仮定した現象 論の計算が行われたが，上り多くの解が得られたのみで，上 述の問題点を解決するには至っていない.

ジルコニアの変態の結晶学で最も困難な点は質の良い大き な $\mathrm{t}$ 相結晶を得ることである. 安定化元素を固溶した比較的 大きな $\mathrm{t}$ 相結晶はフラックス法や溶解法によって得ることが 可能であるが，必ず $\mathrm{t}$ 相の $\mathrm{c}$ 軸が直交する 3 つのヴァリアン トが混在するものとなる. 溶解試料では $\mathrm{c} \rightarrow \mathrm{t}$ 変態を経由し た $\mathrm{t}$ 相の粗大結晶粒が得られるが，この場合 $\mathrm{c} \rightarrow \mathrm{t}$ 変態が無 拡散的に起こるため, 図 3(a)に示すよらな トが規則正しく配列した，いわゆるへリングボーン組織をも
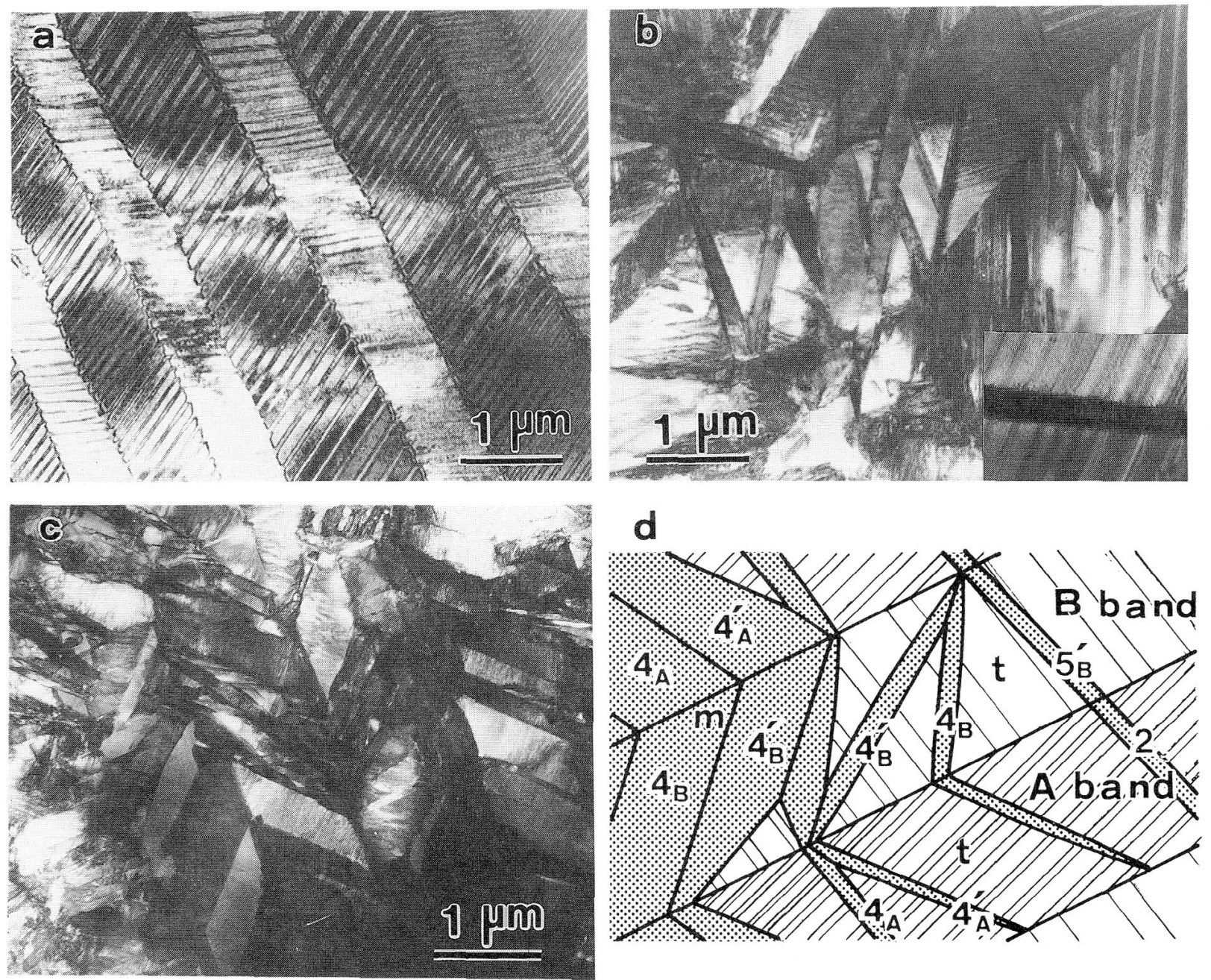

図 3 母相拈よびマルテンサイト組織の電顕写真(試料 : $3 \mathrm{~mol} \% \mathrm{Y}_{2} \mathrm{O}_{3}-\mathrm{ZrO}_{2}$ 溶解試料). (a) 正方晶母相のーリング ボーン組織，（b）板状マルテンサイト执よびマルテンサイト中に見られる微細な筋状コントラスト(右下挿入 図)，（c）板状マルテンサイトが成長・合体したへリングボーン状マルテンサイト，(d) 板状マルテンサイト からへリングボーン状マルテンサイトへの成長過程の模式図. 
つものとなる。この特異な構造は $\mathrm{c} \rightarrow \mathrm{t}$ 変態の歪緩和によっ て説明されている(13)。このように $\mathrm{t}$ 相ヴァリアントが規則 正しく配列していると, 単一の $\mathrm{t}$ 相ヴァリアントでなくと も，これを母相とする $\mathrm{t} \rightarrow \mathrm{m}$ 変態を現象論的に扱うことが可 能となる.

Hayakawa ら (14)(15) 3 mol\% $\mathrm{Y}_{2} \mathrm{O}_{3}$ を含むジルュニアの溶 解試料のへリングボーン $\mathrm{t}$ 相中に生じるマルテンサイトにつ いて結晶学的な解析と現象論的計算を行った．溶解後室温で 観察される典型的なマルテンサイトを図 $3(\mathrm{~b})$ に示す. ヘリ ングボーン母相中に板状あるいはレンズ状に生成して拉り, 通常のマルテンサイトと同様に不変面歪条件を満足するよう に生成していることが推察できる。むた図 3(b)の右下に挿 入したマルテンサイト中には細かい縞状のコントラストが観 察される.この縞状コントラストのトレースは $\{101\}_{\mathrm{m}}$ 面に 一致するが，この面は $\mathrm{m}$ 相の可能なすべり面であることよ り，この面上の $\langle 101\rangle_{\mathrm{m}}$ 扩よび $\langle 010\rangle_{\mathrm{m}}$ 方向すべりを格子不変 歪と仮定した。また，現象論の計算においても母相が $\mathrm{t}$ 相単 一ヴァリアントではなく $(101)_{\mathrm{t}}$ 双晶板の積層であることを 考慮して，式(10)の代わりに次式を仮定している.

\section{$\boldsymbol{S}=\boldsymbol{R} \boldsymbol{P B \boldsymbol { T } ^ { - 1 }}$}

図 4 に示すよらに, ヘリングボーン双晶 (b)から $\mathrm{m}$ 相格子 (c)への格子歪, $\boldsymbol{U}$, は一旦 $\mathrm{t}$ 相単一ヴァリアント (a)へ戻っ てから $\mathrm{m}$ 相格子 $(\mathrm{c})$ 一移る格子歪と算術上同じであるので, 式(10)の $\boldsymbol{B}$ の代わりに $\boldsymbol{B} \boldsymbol{T}^{-1}$ を用いればよいことになる.

母相が双晶板であることより，可能な格子対応は 3 つで

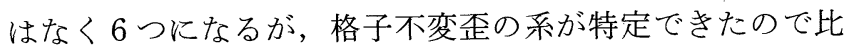
較的少数の解に絞ることができた. 合計 6 個の解が存在し たが，このらち\{101\}〈101 $\rangle_{\mathrm{m}}$ を格子不変歪とした 4 個の解 が晶癖面の一面トレース解析結果とよい一致を示した。これ ら4 個の解は格子対応が異なるが，格子歪は極めて近く実 質上同等の解とみなすことができる. 上記の解については方 位関係に関しても実測值と一致することが示されている.

溶解試料を $400 \sim 600 \mathrm{~K}$ で時効すると上記のマルテンサイ 卜は成長合体し局所的にではあるが完全に母相を埋め尽く
し，最終的には図 $3(\mathrm{c})$ に示すような $\mathrm{m}$ 相のへリングボーン 組織になる(16)。この過程に抢いてマルテンサイト板が長手 方向に成長して $\mathrm{t}$ 相ヘリングボーンのバンド境界を横切ると きに直進するものと屈曲するものとがあるが，これも現象論 の解より予測されるものである(15). なお，図3(d)に $\mathrm{t}$ 相一 リングボーン組織中に板状の $\mathrm{m}$ 相マルテンサイトが生成し, これらが成長・合体して $\mathrm{m}$ 相のへリングボーン組織になる 過程を模式的に示す. 当然のことながら $\mathrm{m}$ 相へリングボー ン構造のヴァリアント境界面は対称性の高い低指数面とな り, 孤立したマルテンサイトの晶癖面とは異なる。したがっ てこのよらな形態のマルテンサイトに現象論を適用するのは 不適当であり, むしろ全体としての剪断歪の緩和機構によっ て説明されるべきものである. $\mathrm{t}$ 相打よび $\mathrm{m}$ 相, さらにス カンジア添加ジルコニアでそれぞれ形態が異なるへリングボ ーン構造が生成するが，いずれの場合も剪断歪の緩和機構に よって説明可能である(17)。このように成長した $\mathrm{m}$ 相のマル テンサイトはヴァリアント間の接合面と晶癖面とは異なる が，個々のヴァリアントは最初孤立して生成したマルテンサ イトが成長したものであるので, 形状丕あるいは表面起伏角 は不変とみなすことができる. 実際, 走査トンネル顕微鏡で 測定した $\mathrm{m}$ 相へリングボーンマルテンサイトの表面起伏角 は現象論の解から予測されるものと良い一致を示した ${ }^{(18)}$.

このように溶解試料の $\mathrm{t}$ 相へリングボーン組織を母相とし て生成怙よび成長するマルテンサイトに関しては現象論的に も整合性のある結晶学的な機構が提案されているが，まだ十 分検証されていない部分も残されている. 晶癖面の解析も一 面解析では説得力に欠ける. またマルテンサイト板中の縞状 コントラストを格子不変すべりと仮定しているが，なぜすべ りによってこのようなコントラストが生じるかも明らかでな い.また，一般的にジルコニアのマルテンサイト変態に格子 不変歪が起こるか否かについても結論はでていない。より良 質な単結晶試料を用いることによりこれらの点が明らかにで きることが期待される.

溶解試料を $400 〜 600 \mathrm{~K}$ で時効したときに成長するマルテ (a) $\mathrm{t}$

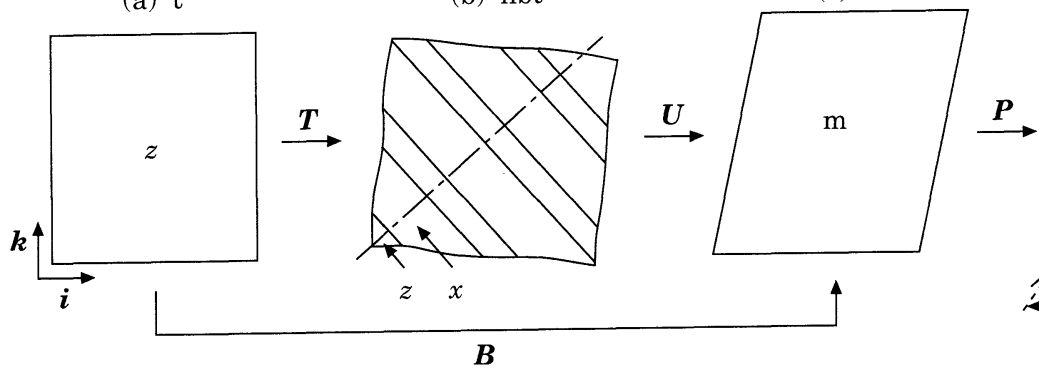

(d) mart.

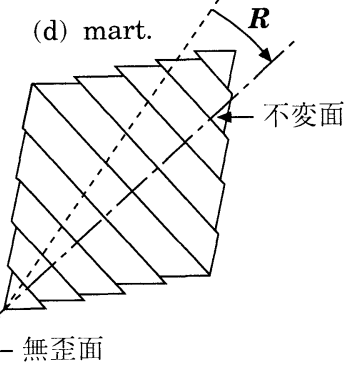

無歪面

図 4 正方晶ヘリングボーン中に板状マルテンサイトが生成する場合の格子歪の概念図，(a) $\mathrm{t}:$ 正方晶 $z$ ヴァリア ント, (b) hbt : 正方晶ヘリングボーン中の双晶, (c) $\mathrm{m}$ : 格子歪後の単斜晶, (d) mart. : 格子歪十格子不変 歪後の単斜晶 (マルテンサイト). 
ンサイトには図 3(c)に示したものとは異なる形態のマルテ ンサイトも見られる(19)。これは図5(a)に示すようにミリ才 ーダの長さをもつ針状のマルテンサイトである. 2 面解析の 結果この針状組織は $\{100\}_{\mathrm{t}}$ 面に乗った板状の組織であるこ とが分かった。電顕観察のためのイオンシンニングではマト リックスが優先的に研磨され, 生成初期の内部構造 (図 5(b)) は明らかにすることはできなかったが，十分成長した段階で は微小なマルテンサイト板の集合であることが分かった（図
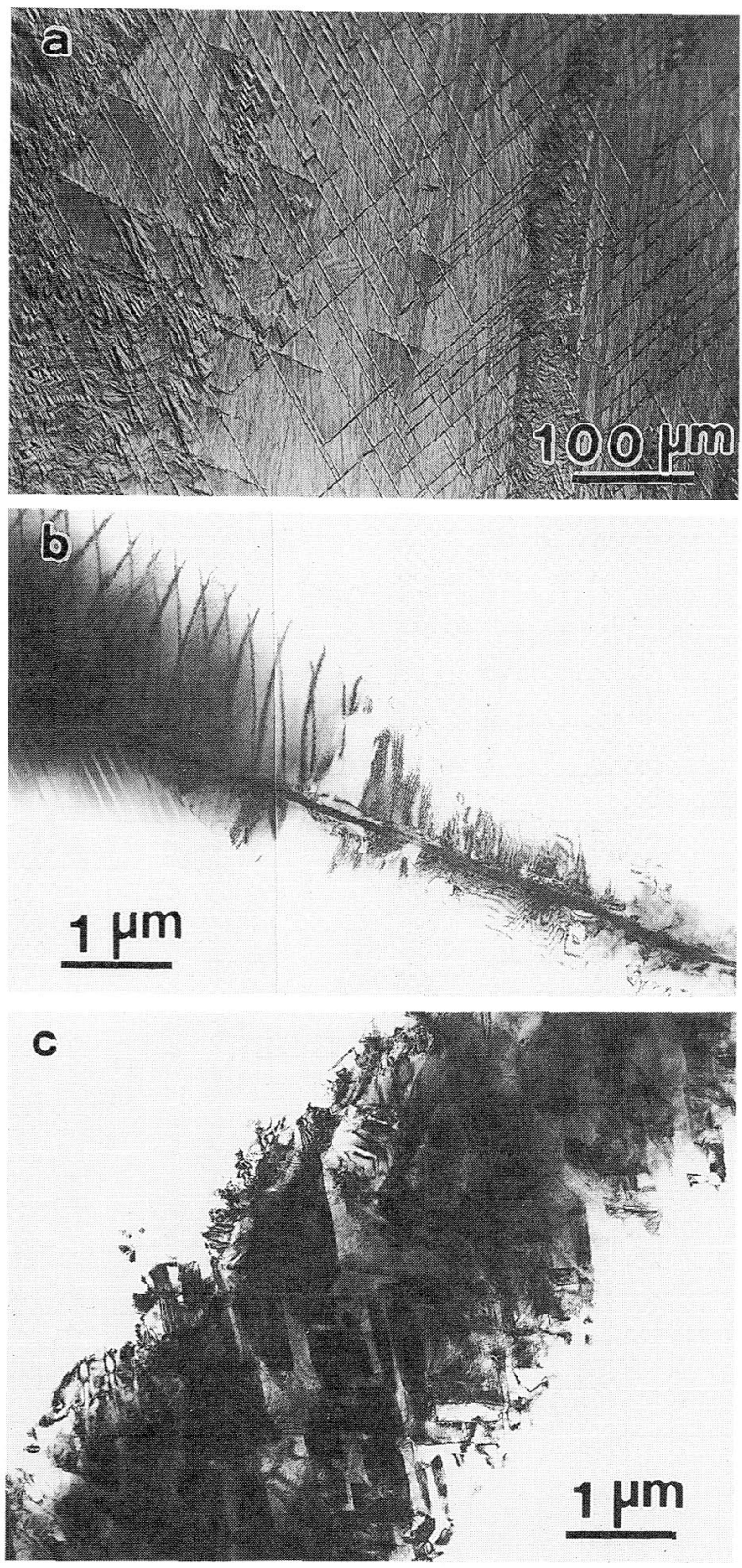

図 5 針状マルテンサイトの組織写真( 試料: 3 $\mathrm{mol} \% \mathrm{Y}_{2} \mathrm{O}_{3}-\mathrm{ZrO}_{2}$ 溶解試料). (a) 表面起伏の光 顕写真(ノマルスキー干渉), (b) 生成初期状熊 の電顕写真, (c) 成長後の電顕写真. 5(c))。また，この針状組織は逆変態温度よりも数百度も高 い $1473 \mathrm{~K}$ まで加熱後室温で観察しても全く同一箅所に再生 することが分かった。これらの事実より (100) t 面上の欠陷 を核として生成すると考光られるが，現時点では溶解後冷却 過程での熱応力により $\mathrm{t}$ 相へリングボーン中の $(100)_{\mathrm{t}}$ 面です ベりが起こり，これがへリングボーン構造の $(101) \mathrm{t}$ 双晶と 交差したところで積層不整による歪が生じ，これを核生成場 所としてマルテンサイトが生じるためと解釈している(19).

\section{4. $M_{\mathrm{s}}$ 温度の粒径依存}

一般にマルテンサイトは母相とマルテンサイト相の熱力学 的平衡温度 $\left(T_{0}\right)$ からの過冷, あるい: $T_{0}$ 以下での応力負荷 によって, ある程度以上の駆動力を得て初めて変態が誘起さ れる、変態誘起勒性を有効に得るためには使用温度(通常は 室温)は $T_{0}$ と $M_{\mathrm{S}}$ (変態開始温度)の間でなければならない。 $M_{\mathrm{S}}$ 温度が使用温度に近い程, 変態に要する駆動力は減少し $\sigma_{\mathrm{m}}^{\mathrm{c}}$ が低下するので, 式 $(7),(8)$ より勒化には都合がよい ことが分かる。しかしながら 2 節の終わりで述べたよら に， $\sigma_{\mathrm{m}}^{\mathrm{c}}$ が低すぎると破壊強度が逆に低下寸るので， $M_{\mathrm{s}}$ は ある程度低く抑觉ることが必要である、実際, 実用化されて いる部分安定化ジルコニアは液体窒素温度に冷却しても $\mathrm{t} \rightarrow \mathrm{m}$ 変態が起こらない淘ど安定である。 $M_{\mathrm{s}}$ を下げる手段 として粒径を微細にすることが有効であることは部分安定化 ジルコニアの発見当初より知られて扣り, 専らこの性筫を利 用して比較的安定度の高い準安定 $\mathrm{t}$ 相を得る努力がなされて きた。このように $M_{\mathrm{s}}$ 温度の粒径依存性は実用的な観点から 重要であるばかりでなく，マルテンサイトの核生成機構を直 接反映した結果であると考觉られるので学問的にも興味深い 現象である。

$M_{\mathrm{s}}$ 温度の粒径依存性は金属材料でも認められているし, セラミックスの場合でも $\mathrm{t}$ 相の形態が微粉末，析出・分散粒 子，多結晶体のいずれの場合でも認められる，この上らに粒 径依存性は一般に認められる現象であるが，その原因は心ず しも同じとは限らないし, 複数の要因が同時に関与している 可能性が高い.このことが問題解決を難しくしていると考兄 られる。

セリア添加ジルコニアは単相型の固溶体であり, 高温加熱 によって結晶粒が成長しやすいので, 粒径依存性を研究する のに都合がよい．図 6 に $12 \mathrm{~mol} \% \mathrm{CeO}_{2}$ 添加ジルュニアにつ いての $M_{\mathrm{s}}$ 温度の結晶粒径依存性を示寸(20)。粒径が $8 \mu \mathrm{m}$ 以 下では液体窒素温度までの泠却では変態しないが，それ以上 では $M_{\mathrm{s}}$ 温度は顕著な粒径依存性を示した。同様の結果が他 の研究者によっても報告されている. $8 \mu \mathrm{m}$ 以下の試料につ いても相の安定性は結晶粒径に依存することが予想される が，このことを確認するために種々の温度で曲げ試験を行っ た．図 7 は曲げ強度の試験温度依存性を種々の結唱粒径をも つ試料についてプロットしたものである。試験温度に対して 


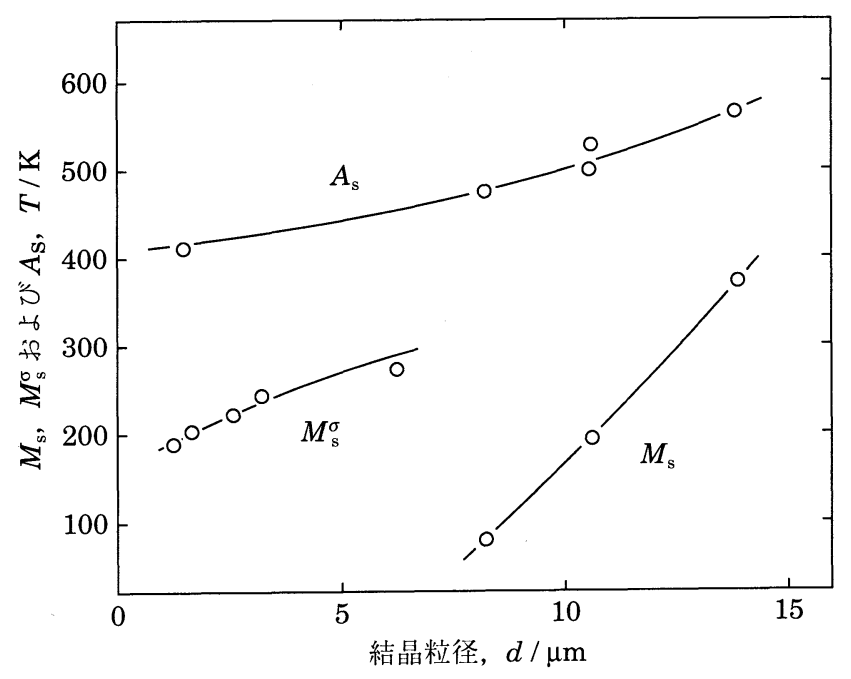

図 $6 M_{\mathrm{s}}, A_{\mathrm{s}}$ および $M_{\mathrm{s}}^{\sigma}$ の結晶粒径依存性(試料 : 12 $\mathrm{mol} \% \mathrm{CeO}_{2}$-TZP).

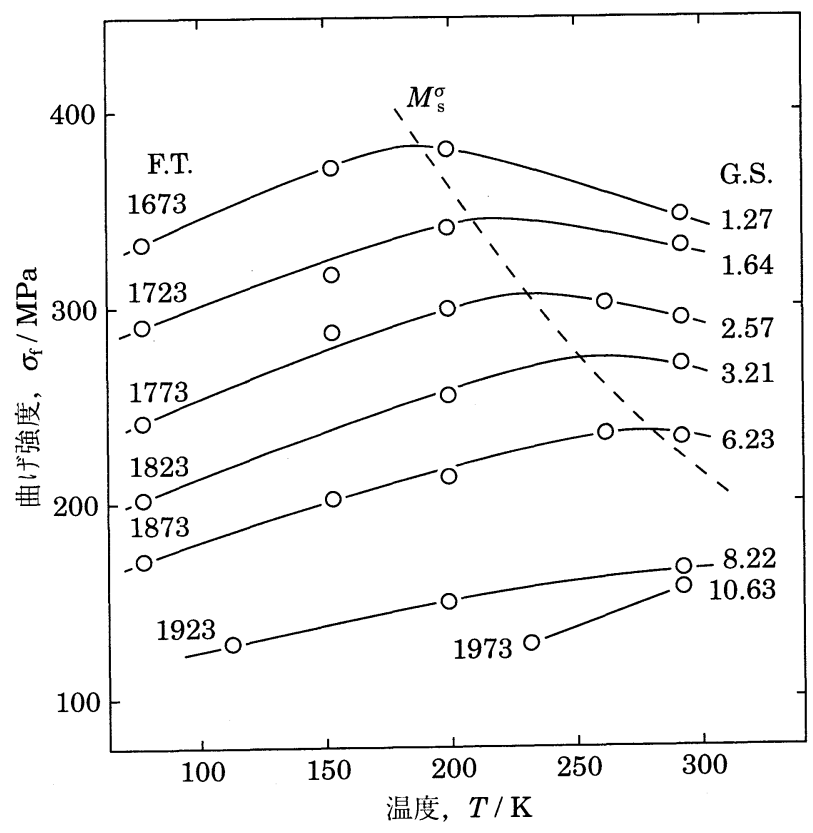

図 7 曲げ強さの温度および結晶粒径の依存性. 図中 の G.S. 打よびF.T.はそれぞれ結晶粒径 $(\mu \mathrm{m})$ および焼結・加熱温度 $(\mathrm{K})$ を示す(試料 : 12 $\left.\mathrm{mol} \% \mathrm{CeO}_{2}-\mathrm{TZP}\right)$.

山形の曲線を描くが，低温側の正の勾配の温度依存性は低温 程 $\sigma_{\mathrm{m}}^{\mathrm{c}}$ が低下することによる．したがって山の頂点を応力誘 起変態が起こる温度の目安 $\left(M_{\mathrm{s}}^{\sigma}\right)$ とすると, この温度は粒径 の粗大化とともに高温側へ移ることより結晶粒が比較的小さ い領域でも相安定性は粒径に依存することが分かる．図 6 には逆変態開始温度 $\left(A_{\mathrm{s}}\right)$ もプロットしてあるが，わずかな がらこれも粒径依存性を示す。しばしば $T_{0}$ 温度は $M_{\mathrm{s}}$ と $A_{\mathrm{s}}$ の平均によって近似されるが， $T_{0}$ 温度はその定義より結晶
粒径に依存しないはずであるので，この試料ではこの近似は 成り立たない。ついでながら図 7 より結晶粒の微細化は高 強度化に極めて有効であることが分かる.

$M_{\mathrm{s}}$ 温度が結晶粒径に依存する要因は幾つか考えられる。 Chen ら (21) は結晶粒の粗大化とともに，より大きなエンブリ オが生成しやすくなるためとしている．かれらは粒界等に $n$ 個の転位が堆積する確率は結晶粒の粗大化とともに大きく なることを統計論的に示している. しかしながらマルテンサ イトの核生成機構自身が十分明らかでないのでモデルの正当 性を評価することは困難である. Heuer ら (22) はアルミナ中 に分散させたジルコニア粒子の相安定性を電子顕微鏡観察に より詳細に調べた. ジルュニア粒子はアルミナの結晶粒界に 存在するものと粒内に存在するものとがあるが，同程度の大 きさの粒子であっても結晶粒界に位置するものは粒内に位置 するものより明らかに不安定であった。このことより Heuer らは熱膨張係数の非等方性による粒界での残留応力 が変態を促進すると考えた。計算によっても非当方的な熱膨 張係数による粒界残留応力は結晶粒径の粗大化とともに大き くなることが示されている(6). 単相型である正方晶ジルュニ ア多結晶体においても正方晶は非等方的な熱膨張係数をもつ ので同様の機構で $M_{\mathrm{s}}$ 温度の粒径依存性に寄与していること が考觉られる。

Hayakawa ら ${ }^{(20)}$ は粒径依存性に対してさらに別の要因を 指摘している. 図 8 は前述の試料について母相の硬さの粒径 依存性を示す. 粒径の粗大化とともに硬さが低下しているが このよらな傾向はセラミックス材料に拈いても一般的にみら れる現象である. 室温に拈ける硬さ測定は局所的な応力誘起 変態の影響を受けている可能性があるが， $A_{\mathrm{s}}$ 温度より十分 高い $773 \mathrm{~K}$ での硬さ值も室温での值と同様の粒径依存性を 示していることより, 応力誘起变態の影響は室温でも無視で

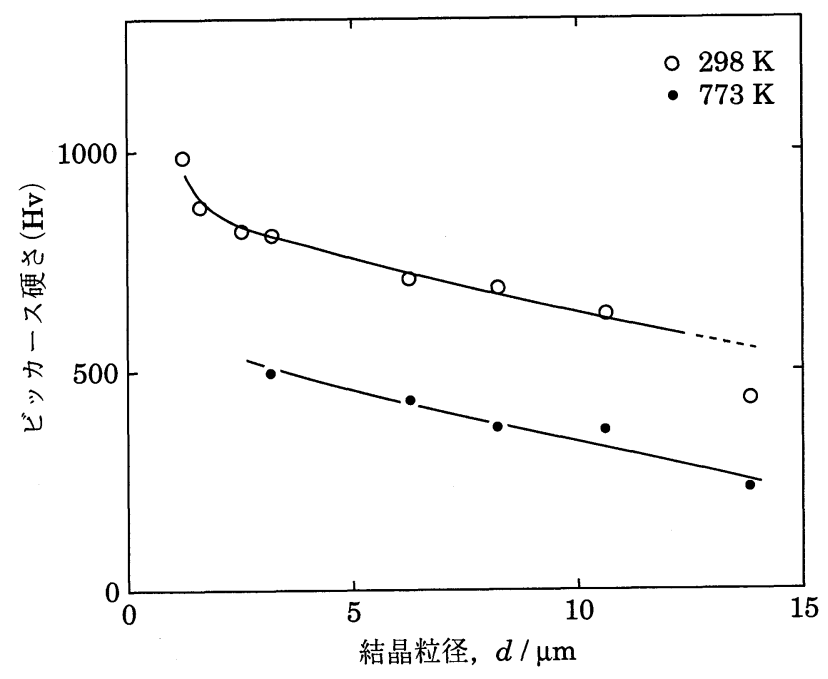

図 8 ビッカース硬さの結晶粒径依存性(試料 : 12 $\left.\mathrm{mol} \% \mathrm{CeO}_{2}-\mathrm{TZP}\right)$. 
きると考えられる.マルテンサイト変態が起こるには, まわ りの母相が変態歪をある程度緩和する必要があるので, 変態 の容易さは母相強度に依存する. 図 8 に示す強度は結晶自 身の硬さではなく粒界の影響を含む平均的な硬さではある が，金属材料の場合 ${ }^{(23)}$ と同様に平均強度がマルテンサイト 変態の容易さに影響を及洔すことはあり得ると著者らは考兄 ている.

このようにジルュニアの粒径依存については種々の要因が 考光られてるが，個々の要因の定量的な寄与の評価につい ては今後の課題である.

\section{5. あと がき}

ジルコニア系セラミックスのマルテンサイト変態に関し て, その結晶学的機構と結晶粒径依存性ついて著者らの研究 結果を中心に述べた. 等温マルテンサイト変態もジルコニア 系マルテンサイト変態の中心的課題の 1 つであるが, 紙面 の都合上割愛した.

マルテンサイト変態に関する研究は金属材料では長い歴史 があるので, セラミックスのマルテンサイト変態に関して研 究方針を立てるのは容易である。しかしながら，セラミック ス材料で高品質のデータを得ることに関しては困難がつきま とら．例えば，金属材料で一般に用いられる溶解と均一化焼 鈍が通常セラミックスでは困難である. 実用的セラミックス 材料は殆ど焼結法で作られるが, 結晶粒径が微細な上, その 性質は出発原料の不純物や粒の状態, さらに焼結条件等によ って変わる. そのため類似の試料であっても研究者間でデー タの共用や比較が困難になる。これらの問題を解決するため には良好な試料の作成技術や材料のキャラクタライゼーショ ン技術の発展を期待したい。

\section{文献}

(1) R. C. Garvie, R. H. Hannink and R. T. Pascoe: Nature,
258 (1975), 703.

( 2 ) T. K. Gupta, J. H. Bechtold, R. C. Kuznicki, L. H. Gadoff and B. R. Rossing: J. Mater. Sci., 12 (1977), 2421.

( 3 ) N. Claussen: Adv. Ceram., Vol. 12, Science and Technology of Zirconia II, Ed. N. Claussen, M. Rühle and A. H. Heuer, (1983), 325.

(4) H. G. Scott: J. Mater. Sci., 10(1975), 1527.

( 5 ) D. J. Green, R. H. J. Hannink and M. V. Swain: Transformation Toughening of Ceramics, CRC Press Inc., Boca Raton, Florida, (1989), Chpt. 3.

(6) A. G. Evans and R. M. Cannon: Acta Metall., 34(1986), 761.

( 7 ) G. B. Olson: Martensite, Ed. G. B. Olson and W. S. Owen, ASM International, (1992), 1.

( 8 ) C. M. Wayman: Introduction to the Crystallography of Martensitic Transformations, The MacMillan Co., New York, (1964).

( 9 ) G. K. Bansal and A. H. Heuer: Acta Metall., 20 (1972), 1281.

(10) G. K. Bansal and A. H. Heuer: Acta Metall., 22 (1974), 409.

(11) W. M. Kriven, W. L. Fraser and S. W. Kennedy: Adv. Ceram., Vol. 3, Science and Technology of Zirconia, Ed. A. H. Heuer and L. W. Hobbs, (1981), 82.

(12) M. A. Choudhry and A. G. Crocker: Adv. in Ceram., Vol. 12, Science and Technology of Zirconia III, Ed. N. Claussen and A. H. Heuer, (1983), 46.

(13) M. Hayakawa, M. Tada, H. Okamoto and M. Oka: Trans. JIM, 27 (1986), 750.

(14) M. Hayakawa, N. Kuntani and M. Oka: Acta Metall., 37 (1989), 2223.

(15) M. Hayakawa and M. Oka: Acta Metall., 37(1989), 2229.

(16) M. Hayakawa, M. Adachi and M. Oka: Acta Metall. Mater., 38(1990), 1753.

(17) M. Hayakawa and M. Oka: Mater. Sci. Forum, Vols. 56-58, Martensitic Transformations I, Ed. B. C. Muddle, Trans. Tech. Publications, (1990), 383.

(18) M. Yamamoto, T. Fujisawa, T. Saburi, M. Hayakawa, M. Oka, M. Kurumizawa and K. Kusano: Ultramicroscopy, 42-44 (1992), 1422.

(19) M. Hayakawa, Y. Onda and M. Oka: Proc. ICOMAT-92, (1993), 707

(20) M. Hayakawa, H. Shinmen and M. Oka: Proc. ICOMAT-92, (1993), 677.

(21) I-W. Chen, Y-H. Chiao and K. Tsuzaki: Acta Metall., 33 (1985), 1847.

(22) A. H. Heuer, N. Claussen, W. M. Kriven and M. Rühle: J. Amer. Ceram. Soc., 65(1982), 642.

(23) S. Kajiwara: Metall. Trans. A, 17A(1986), 1693.

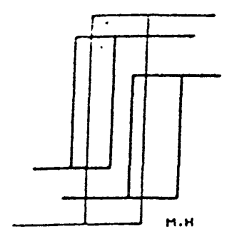

